DOI: $10.15290 /$ mwtusbwsdb.2019.05

Cezary Kuklo

\title{
ROLA KOŚCIOŁA RZYMSKOKATOLICKIEGO W DZIEJACH NARODU I PAŃSTWA POLSKIEGO 1918-2018
}

Rola Kościoła rzymskokatolickiego w dziejach narodu i państwa polskiego 1918-2018 to temat niezwykle ważny i głęboki, ale zarazem obszerny, obliczony, w moim przekonaniu, na tomy książek napisanych przez wieloosobowe zespoły badaczy i autorów. Nie mogłem jednak odmówić prośbie księdza Rektora naszego Seminarium, stąd mój artykuł, biorąc pod uwagę także charakter uroczystości, ma siłą rzeczy - co zaznaczam postać mocno syntetyczną.

Jeszcze zanim powstało niepodległe Państwo Polskie trzeba podkreślić, że to właśnie czynnik religijny kształtował w XIX wieku postawę większości grup społecznych, gdyż w dwu dzielnicach: pruskiej i rosyjskiej zaborca był kimś zdecydowanie obcym nie tylko politycznie, ale i wyznaniowo. Konflikty między polskim Kościołem a carską schizmą czy protestanckim prusactwem tj. kasata Unii, z drugiej strony Kulturkampf, były obroną przed wynaradawianiem wielu skupisk polskich: na Śląsku, na Mazurach, a zwłaszcza na wschód od Bugu. Nie będzie zatem żadnej przesady w stwierdzeniu, że w dobie zaborów, w dobie, kiedy nie było państwa polskiego Kościół katolicki był podstawową instytucją narodową.

Świeżo co odzyskanej niepodległości u schyłku 1918 roku przyszło bronić przed nawałą bolszewicką, niosącą na bagnetach na Zachód ideologię komunistyczną. Duchowni wszystkich szczebli bez względu na sympatie polityczne latem 1920 roku aktywnie włączyli się w działania między innymi apelując do społeczeństwa, o masowy zaciąg do wojska. Typowym przykładem postawy duchowieństwa był 27-letni ks. Ignacy Skorupka, który na ochotnika zgłosił się na kapelana wojskowego 36 pułku Legii Akademickiej i szedł w pierwszym szeregu razem $\mathrm{z}$ dowódcą batalionu, zagrzewając żołnierzy do walki 14 sierpnia w boju pod Ossowem, będącej częścią „Bitwy Warszawskiej”, w którym zginął. Z kolei, bliski naszym

Wykład inauguracyjny wygłoszony w dniu 28 września 1918 r. w Archidiecezjalnym Wyższym Seminarium Duchownym w Białymstoku. 
sercom bp Romuald Jałbrzykowski, późniejszy Metropolita Wileński, kierował w 1920 roku Komitetem Obrony Łomży

Jednakże wraz z odzyskaną niepodległością uległy przemianom ramy organizacyjne nie tylko życia politycznego, ale jeszcze bardziej społeczno-kulturalnego Kościoła, zniknęły bowiem ograniczenia zaborców i cenzura. Z drugiej strony, w okres niepodległego bytu społeczeństwo weszło z całym bagażem po rządach zaborczych - przede wszystkim potężnym zacofaniem ekonomicznym i kulturalnym. I choć stosunki wyznaniowe charakteryzowały się przewagą katolicyzmu ponad $62 \%$ według spisu z 1921 deklarowało obrządek łaciński, to ponad 1/3 ludności była wyznawcami innych konfesji. II Rzeczpospolita powstała bowiem jako państwo wielonarodowe, w którym obok blisko 19 mln Polaków, żyło około $5 \mathrm{mln}$ Ukraińców, $2 \mathrm{mln}$ Żydów, 1,5 mln Białorusinów i około 1 mln Niemców. Ogromne były przy tym różnice w poziomie życia i mocno zróżnicowane postawy polityczne społeczeństwa wyrażane udziałem w ówczesnych partiach. Wystarczy przypomnieć ostrość debat parlamentarnych między stronnictwami prawicowo-centrowymi a przedstawicielami mniejszości religijno-narodowych i lewicy zakończonych kompromisem w Konstytucji z marca 1921 roku „że wyznanie rzymskokatolickie, będące religią przeważającej części narodu, zajmuje w państwie naczelne stanowisko wśród równouprawnionych wyznań", co powtórzono w Konstytucji 1935 roku. Obok Konstytucji, podstawowym dokumentem regulującym sprawy Kościoła stał się konkordat ze Stolicą Apostolską zawarty w 1925 roku, stwarzający ramy bardzo dla Kościoła korzystnej, samodzielnej działalności. Stosunki Kościół - państwo, mimo wielu głośnych zatargów z pojedynczymi biskupami, zwolennikami Narodowej Demokracji, a po zamachu majowym 1926 roku, przeciwnikami Józefa Piłsudskiego, układały się na ogół przez cały czas dobrze. Dbała o to zarówno Stolica Apostolska przez swych nuncjuszy, a trzeba pamiętać, że miała ona dobre rozeznanie, wszak papież Pius XI sam był nuncjuszem w Polsce u progu naszej odzyskanej niepodległości, ale i rozważny młody - 45-letni Prymas od czerwca 1926 roku August Hlond, który tak mówił: „prosto do celu, nie ustępując w niczym, gdy chodzi o dobro Kościoła, ale unikając także wszystkiego tego, co może wywołać niepotrzebne i szkodliwe napięcie”. Trzeba powiedzieć, że rychło wyniesiony do godności kardynalskiej, Prymas Hlond umiał spokojnie i stanowczo narzucić swój autorytet biskupom, nierzadko zapatrzonym w długi wiek XIX i całemu Episkopatowi. Z jego inicjatywy zaczęły w nim powstawać specjalne komisje dla realizacji konkretnych zadań w skali całego kraju.

Zniszczenia wojenne i rabunkowa gospodarka zaborców (90\% obszaru Polski było terenem działań wojennych) nie ominęły infrastruktury 
kościelnej: kościołów, plebanii, budynków instytucji i sprzętu liturgicznego, co w pierwszym rzędzie zmuszało Episkopat do działań na rzecz ich odbudowy, z drugiej, konieczność ujednolicenia wielu spraw, w tym przebudowy i rozbudowy samej organizacji terytorialnej, co stało się faktem jesienią 1925 roku bullą papieską Vixidum Poloniae unitas. Ważnym wydarzeniem w życiu Kościoła było przygotowanie synodu plenarnego w sierpniu 1936 roku, poprzedzonego 8-letnią pracą, licznymi posiedzeniami Episkopatu, zebraniem materiałów na temat życia kościelnego na ziemiach polskich pod kątem jego braków i potrzeb.

Zwiększała się powoli liczba księży, która przekroczyła 10 tys. diecezjalnych i blisko 2 tys. zakonnych w 1939 roku. Kładziono nacisk na podniesienie poziomu Seminariów funkcjonujących w każdej diecezji. Utworzono 3 nowe Wydziały teologii katolickiej w Warszawie, Wilnie i w nowo otwartym w 1918 roku Uniwersytecie Katolickim w Lublinie, choć ten ostatni był programowo nastawiony na kształcenie inteligencji świeckiej. Zdecydowany postęp widać też w zakresie życia zakonnego, wzrasta ich liczba, także liczba zakonników do ponad 7 tys. oraz sióstr do blisko 22 tys., choć mimo podejmowanych wysiłków, dysproporcje w ich rozprzestrzenianiu są ogromne: przoduje Małopolska i Górny Śląsk. Jedną z najbardziej charakterystycznych cech działalności zakonów dwudziestolecia była rozbudowa wydawnictw religijnych różnego typu zgodnie z wielkimi, wyraźnie w miarę szybkiej alfabetyzacji rosnącymi potrzebami masowymi. Nie sposób nie zaakcentować działalności szkolno-wychowawczej, w której szczególnie dynamicznymi byli salezjanie z 30 zakładami kształcącymi i wychowującymi zwłaszcza młodzież męską w praktycznych zawodach. Zgromadzenia żeńskie były wszędzie tam, gdzie instytucje społeczne, samorządowe i państwowe nie były w stanie sprostać potężnym ówczesnym problemom społecznym: edukacji dzieci i młodzieży oraz zadaniach charytatywnych. Siostry, głównie urszulanki, prowadziły około $40 \%$ istniejących w całym kraju przedszkoli, setki internatów dla młodzieży, kilkaset szkół, w tym 50 liceów i 12 seminariów nauczycielskich.

Kościół był uważnym uczestnikiem życia społecznego w II Rzeczypospolitej i to bynajmniej niebezkrytycznym. Koniec lat dwudziestych i początek lat trzydziestych charakteryzował się większymi lub mniejszymi tendencjami autokratycznymi, w wielu krajach Europy, podsycanymi pogłębiającym się kryzysem gospodarczym i niezadowoleniem mas. Encyklika papieża Piusa XI - Quadrogesimo Anno (z marca 1931) stała się podstawą listu pasterskiego Prymasa Polski kard. Augusta Hlonda z 23 kwietnia 1932 roku O chrześcijańskie zasady życia państwowego. Prymas zwracał w nim uwagę, że „Państwo jest dla obywateli, a nie obywatele dla państwa”. Potępiono gwałt w życiu politycznym i utożsamianie państwa 
z grupą rządzącą. Stwierdzono, iż najważniejszym zadaniem państwa jest koordynacja interesów różnych grup społecznych, a nie umacnianie własnej wszechwładzy. Krytyce totalitaryzmów widocznych w krajach po zachodniej i wschodniej granicy Polski i oględnemu wskazaniu podobnych tendencji w Polsce towarzyszyły zarazem postulaty reform, mających na celu ulżenie grupom najbardziej upośledzonym ekonomicznie.

Dla opracowania programu tych reform Episkopat powołał w 1933 roku Radę Społeczną przy Prymasie Polski, którą kierował ks. Antoni Szymański, rektor KUL, ale i zarazem wybitny profesor nauk społeczno-ekonomicznych. Nowoczesne idee katolicyzmu społecznego upowszechniała jednocześnie wśród świeckich założona w 1930 roku Akcja Katolicka. Jej celem była obrona zasad moralnych i religijnych w życiu społecznym pod przewodnictwem hierarchii kościelnej, niezależnie od partii politycznych.

Stanowisko rządu wobec Akcji Katolickiej początkowo niechętne, od 1934 roku stało się zdecydowanie pozytywne, czego wyrazem było przyznanie jej szerokich uprawnień. Jednocześnie słabością masowej organizacji (w 1939 roku liczyła do 750 tys.) była jej zbytnia bierność, atmosfera znacznego podporządkowania, idącym od góry zaleceniom. Była obecna przede wszystkim w środowiskach wiejskich, dużo słabiej w środowiskach robotniczych. Obok Akcji Katolickiej powstało wiele różnych organizacji czy bardziej ruchów różnego typu, ważnych dla kultury religijnej kraju. Wciąż jeszcze czekają one na swoje prace krytyczno-historyczne pozwalające na pełniejszą ocenę ich znaczenia w międzywojennej Polsce. Natomiast $\mathrm{z}$ całą pewnością $\mathrm{w}$ tym okresie wzrósł wzmocnieniu ruch kadry inteligenckiej o pogłębionej świadomości religijnej. Zwracają tutaj uwagę nie tylko dokonania kadry KUL-owskiej, ale także dwa nazwiska. Ojca Jacka Woronieckiego, dominikanina, kładącego podwaliny głębokiej reformy dominikanów polskich, która w następnych dziesięcioleciach pozwoliła właśnie temu zakonowi odegrać wyjątkową rolę w obrębie inteligencji polskiej. Drugą postacią jest ks. Władysław Korniłowicz, którego wspólne dzieło z matką Elżbietą Czacką - zakład dla ludzi ociemniałych w Laskach pod Warszawą, stał się prawdziwym domem dla wszystkich ludzi szukających Boga bez cienia najmniejszej dyskryminacji jakiegokolwiek rodzaju. W pamięci białostoczan pozostaną wybitne postaci duchownych jak ks. Stanisław Hałko, który w 1919 roku został posłem do Sejmu Ustawodawczego, a który zginął w niemieckim obozie koncentracyjnym w Auschwitz i ks. Adam Abramowicz, budowniczy kościoła św. Rocha, pomnika Niepodległości, w przyszłym roku minie 50. rocznica Jego śmierci.

Lata 1939-1945, a w moim przekonaniu tę datę należy przesunąć aż po 1956 rok przyniosły społeczeństwu polskiemu i Kościołowi katolickiemu 
tragiczne wydarzenia i przemiany tak głębokie, że trudno szukać analogii do nich w okresie wcześniejszym. Sowieci, dążąc do szybkiego zniszczenia struktur państwa polskiego i jego elity, wśród których byli duchowni, podjęli działania mające na celu radykalne ograniczenie roli Kościoła i wiary. Zbyt dobrze zdawali sobie sprawę, że katolicyzm na Kresach Wschodnich był niemalże identyczny z polskością. Nie decydując się na powszechne (poza wyjątkami) zamykanie świątyń, uderzyli przede wszystkim w materialne podstawy Kościoła. Praktycznie upaństwowiono wszystko, co było tylko możliwe. Zlikwidowano wszelkie organizacje i instytucje kościelne, bractwa i stowarzyszenia, instytucje charytatywne. Zamknięto Wyższe Seminaria Duchowne, klasztory i zakony. Z gmachów publicznych zniknęły wszystkie symbole religijne. Kurie biskupie i hierarchów wyrzucono z ich pomieszczeń, mienie konfiskowano. W październiku 1939 roku nie wznowiły już pracy szkoły prowadzone przez kościoły i zakony, zamknięto szkolne kaplice. Usunięto z programów nauczania religię, historię i geografię Polski. Księżom zakazano wstępu do szkół, podobnie jak do szpitali spieszących tam z sakramentami dla chorych. W przejętych budynkach umieszczano różne instytucje (na przykład więzienia), często profanowano je urządzając w nich stajnie, kantyny nie mówiąc już o muzeach ateizmu. Niezwykle dotkliwą formą walki z Kościołem było nałożenie przez władze na parafie, świątynie i księży wysokich podatków „od kultu”

Polityka kościelna okupanta niemieckiego była bardziej zróżnicowana. Na terenach włączonych bezpośrednio do Rzeszy tj. Śląska, Pomorza Gdańskiego i Wielkopolski („kraj Warty”) przeznaczonych do zgermanizowania i skolonizowania, władze niemieckie, podobnie jak sowieckie, zmierzały do całkowitej likwidacji polskiej organizacji kościelnej, do usunięcia lub wyniszczenia polskiego duchowieństwa i zastąpienia go księżmi narodowości niemieckiej. Z kolei w Generalnym Gubernatorstwie represje stosowane były na znacznie mniejszą skalę, choć oczywiście starano się ograniczyć działalność i rolę Kościoła, a w dalszej perspektywie przekształcić go w posłuszne narzędzie realizacji własnych celów politycznych. I tak nie została przerwana działalność Kurii biskupich, dekanatów i większości parafii, także domów zakonnych. Jednakże Kościół został pozbawiony prawa roztaczania opieki duszpasterskiej w więzieniach, obozach koncentracyjnych, obozach pracy. Za elementy patriotyczne w kazaniach groziły ostre represje.

W skali strat poniesionych przez poszczególne grupy społeczne i zawodowe duchowieństwo, jeśli nie liczyć ludności żydowskiej, okazało się grupą, która poniosła największe procentowo ofiary osobowe. Stale uzupełniane i wciąż jeszcze niekompletne statystyki dowodzą śmierci około 2 tys. księży diecezjalnych (w tym 6 biskupów), do tysiąca zakonników 
i ponad 300 sióstr zakonnych. Żmudne, ale jakże cenne badania ks. prof. Tadeusza Krahela nad martyrologią duchowieństwa Archidiecezji Wileńskiej ukazały jej rozmiary - z rąk niemieckiego i sowieckiego okupanta zginęło ogółem 122 duchownych, a 330 dalszych doznało rozmaitych represji. W niektórych diecezjach straty księży wyniosły nawet $50 \%$ stanu przedwojennego. Kościół jednak z wojny wychodził z olbrzymim, stale rosnącym własnym prestiżem. We wszystkich warstwach zanikał silny przed wojną, w niektórych środowiskach, antyklerykalizm, zaś uosobieniem prestiżu Kościoła stała się nieugięta osoba Arcybiskupa Krakowskiego Adama Stefana Sapiehy, który po uwięzieniu przez Niemców Prymasa Hlonda we Francji południowej w 1942 roku, stawał się pierwszoplanową postacią w życiu kościelnym kraju o uznawanym przez wszystkich autorytecie tak kościelnym jak i narodowym.

W latach wojny i okupacji księża brali udział w organizowaniu tajnego szkolnictwa z uniwersytetami włącznie (udzielono święceń około 1200 alumnom); byli kapelanami oddziałów partyzanckich, w tym podziemnej i powstańczej Warszawy (ks. Stefan Wyszyński); angażowali się w ratowanie i pomoc najbardziej potrzebującym, dzieciom, ludziom starym, wysiedlonym, pozbawionym pracy, zamkniętych w więzieniach i obozach, w tym także - co podkreślam - Żydom. To właśnie księża katoliccy na potrzeby Rady Pomocy Żydom działającej pod kryptonimem "Żegota” przy Delegaturze Rządu RP na Kraj, dostarczali świadectw metrykalnych chrzestnych i ślubnych, czynił tak między innymi ks. Adam Abramowicz, proboszcz parafii św. Rocha w naszym mieście, ukrywali Żydów na przykład w zgromadzeniach zakonnych. Tylko w jednym zgromadzeniu Sióstr Franciszkanek Rodziny Marii udzielono co najmniej tysiąc kilkuset osobom narodowości żydowskiej, a w kilkudziesięciu sierocińcach ukryto około 500 dzieci.

W kraju stopniowo zajmowanym od lipca 1944 roku przez wojska sowieckie i polskich zesłańców z armii Berlinga, z podążającymi za nimi oddziałami NKWD, przy pogrążającym się coraz bardziej w sporach politycznych rządzie londyńskim, wobec braku zorganizowanej opozycji, w Kościele, pomimo jego strat osobowych i materialnych, społeczeństwo widziało ostatnią niezależną instytucję, zdolną przeciwstawić się komunizmowi. Ale z roli i pozycji Kościoła zdawali sobie sprawę także komuniści, którzy od 1948 roku podjęli zdecydowane i coraz silniejsze ataki. $\mathrm{Na}$ mocy dekretu „O ochronie sumienia i wyznania” zlikwidowano wiele stowarzyszeń kościelnych, instytucji charytatywnych i oświatowych. Podejmowano też próby przeciwstawienia niższego duchowieństwa hierarchii, czemu miał służyć zorganizowany przy Związku Bojowników o Wolność i Demokrację ruch „księży patriotów”. Tylko dwóch takich księży udało 
się pozyskać w diecezji wileńskiej. Kościół - po śmierci kard. Hlonda w październiku 1948 roku kierowany przez nowego Prymasa Polski Stefana Wyszyńskiego, wyszedł z tych pierwszych ataków ograniczony w swoich możliwościach, ale wciąż - co podkreślam - niepoddany kontroli. Napór władzy komunistycznej nie został zahamowany nawet po podpisaniu w kwietniu 1950 roku porozumienia między państwem a Kościołem. Do więzień szli nawet biskupi nie mówiąc już o zwykłych duchownych, organizowano im procesy pokazowe, z Ziem Zachodnich usunięto administratorów apostolskich, wypierano religię ze szkół, wojska, szpitali, zawieszono „Tygodnik Powszechny”. Stawiano na rozbicie nie tylko Kościoła, ale i wiernych kreując jako wzór nowych postaw społeczno-politycznych powołany w 1952 roku przez Bolesława Piaseckiego, współzałożyciela przedwojennego ONR Falangi - Stowarzyszenia PAX, które skądinąd odegrało później pozytywną rolę dając pracę wielu osobom odrzuconym przez system.

Odpowiedzią Prymasa były wypowiedziane publicznie słowa 4 czerwca 1953: „Rzeczy Bożych na ołtarzach Cezara składać nam nie wolno. Non possumus". Trzy miesiące później Prymas został internowany, a jego najbliższego współpracownika i sekretarza bp. Antoniego Baraniaka aresztowanego wraz $\mathrm{z}$ nim, poddano bezlitosnym przesłuchaniom $\mathrm{w}$ więzieniu śledczym na warszawskim Mokotowie przez 27 miesięcy. Torturami, biciem i głodzeniem śledczy z UB chcieli wymusić na bp. Baraniaku zeznania pozwalające na zorganizowanie pokazowego procesu internowanego kard. Wyszyńskiego. W przeciwieństwie do Prymasa, w stosunku do którego komuniści nie odważyli się zastosować przymusu fizycznego, jego sekretarz trafił do największej katowni dla więźniów politycznych przy ul. Rakowieckiej.

Przetasowania w całym obozie komunistycznym po śmierci Stalina i wystąpieniach robotników umożliwiły powrót do władzy Gomułki, który szukał choćby chwilowego kompromisu z Kościołem. Naprzeciw temu wyszedł uwolniony w październiku 1956 roku Prymas Wyszyński, który choć koncyliacyjnie, ale bez niedomówień przedstawił listę oczekiwań w imieniu katolików i duchownych. Już trzy-cztery lata później niewiele zostało $\mathrm{z}$ dawnego kompromisu. Tłem konfliktu dla komunistów stała się zainaugurowana w 1956 roku dziesięcioletnia nowenna na Tysiąclecie Chrztu Polski, której zwieńczenie wiosną 1966 roku było postrzegane przez władze jako bezpośrednie zagrożenie i rodzaj krucjaty. Gorączka propagandowa wymierzona w Kościół i jego hierarchów i wiernych osiągnęła swój szczyt po wystosowaniu przez Episkopat „Orędzia biskupów polskich do ich niemieckich braci w Chrystusowym urzędzie pasterskim”. Niespotykany wcześniej masowy udział katolików w obchodach 
Milenium wbrew oficjalnym manifestacjom, festynom i zawodom sportowym, poparcie aresztowanym w 1968 roku studentom i zrewoltowanym robotnikom na Wybrzeżu w grudniu 1970 roku, mobilizowało wiernych wokół Kościoła, umocniło rolę Prymasa, który stawał się teraz superarbitrem w konflikcie władzy ze znaczną częścią społeczeństwa. Starano się za wszelką cenę śledzić poczynania Kościoła; w 1973 roku osławiony Departament IV, który zajmował się „wrogą antypaństwową działalnością kościołów i związków wyznaniowych", tylko na szczeblu centralnym liczył prawie 900 osób! Wprawdzie nie podejmowano bardziej zdecydowanych działań, ale nadal próbowano zniechęcać hierarchię i księży do opozycji, wywoływać wewnętrzne konflikty, posługując się agenturą. Co istotne, Kościół nie tracił inicjatywy, przede wszystkim urozmaicał formy duszpasterskie wśród młodzieży (ruch oazowy), coraz większą rolę odgrywały Kluby Inteligencji Katolickiej. Znaczna część społeczeństwa postrzegała Kościół jako stabilną, mocną przeciwwagę dla zdemoralizowanej władzy. Nie do przecenienia było niejako cudowne podniesienie prestiżu Kościoła poprzez wybór w październiku 1978 roku na papieża abp. Karola Wojtyły, i jego pierwsza, rok później, pielgrzymka do kraju, co było szokiem dla władz. Księża wsparli też wystąpienia robotników latem 1980 roku i rodzącą się „Solidarność”, choć po śmierci Prymasa Tysiąclecia w maju 1981 roku, nowy Prymas Józef Glemp, nie miał takiej siły perswazyjnej między kierownictwem PZPR i „Solidarności” z Wałęsą na czele. W stanie wojennym decydenci komunistyczni zdawali sobie sprawę z pozycji Kościoła, ale nie zamierzali bynajmniej scedować nań „rządu dusz”. Wydawano bez wahania pozwolenia na budowę nowych kościołów, zgodzono się na ryzykowną dla nich drugą pielgrzymkę Papieża do Ojczyzny, nie stawiano przeszkód działalności charytatywnej, ale jednocześnie wspierano uległe politycznie środowiska katolików świeckich, rozbudowywano intensywnie „pion kościelny” w MSW, atakowano poszczególnych duchownych oraz obecność symboli religijnych w szkołach i fabrykach, nasilono kampanię antyklerykalną. Akcja ta osiągnęła kulminację w porwaniu i bestialskim zamordowaniu 19 października 1984 roku przez funkcjonariuszy SB ks. Jerzego Popiełuszki, syna ziemi podlaskiej, znanego z odprawiania Mszy św. za Ojczyznę, w warszawskim kościele św. Stanisława Kostki na Żoliborzu. Tych ofiar było więcej: ks. Stefan Niedzielak, ks. Stanisław Suchowolec, ks. Sylwester Zych.

Trzeba było następnych czterech lat, galopującego kryzysu ekonomicznego, apatii i marazmu, wstrząsanych kolejnymi strajkami przede wszystkim na Śląsku i Wybrzeżu, aby władze zdecydowały się na podjęcie najpierw poufnych, a następnie oficjalnych rozmów ze stroną solidarnościową. Pośredniczyli w nich przedstawiciele Episkopatu, o czym niektórzy 
atakujący ustalenia „Okrągłego stołu” wolą nie pamiętać, a mianowicie: abp Bronisław Dąbrowski, bp Jerzy Dąbrowski i ks. Alojzy Urszulik. Po 1989 roku w nowej sytuacji znalazł się Kościół, który walnie przyczynił się do podtrzymania ducha wolności w kraju i do łagodnego upadku rządów komunistycznych. Nastąpiła normalizacja stosunków między Warszawą a Watykanem, nie bez napięć przywrócono nauczanie religii w szkołach od września 1990 roku. Kapłani pojawili się na trwale w wojsku, szpitalach, więzieniach, w innych formacjach, przede wszystkim mundurowych. Niekiedy pojawiały się postawy tryumfalizmu, wsparte ambicjami polityków licytujących się przywiązaniem do katolicyzmu, a w życiu prywatnym, nie mówiąc już o publicznym, żyjących „na bakier” z Dekalogiem. Z drugiej strony, nie brakło głosów kwestionujących prawo Kościoła do zajmowania stanowiska w sprawach politycznych, choć nierzadko wygłaszali je ci, którzy wcześniej domagali się takiego zaangażowania.

Nie ulega wątpliwości, że Kościół, co wynika z badań opinii publicznej tak świeckich jak i katolickich instytucji, pozostaje nadal ogromną siłą społeczną i moralną, a świątynie nadal są pełne. Zmienia się jednakże miejsce religii i Kościoła w życiu Polaków, a Kościół i jego wyznawcy stają wspólnie u progu drugiego stulecia niepodległości, przed nowymi problemami i zadaniami. Zbiega się to z pogłębiającymi podziałami politycznymi wewnątrz społeczeństwa i tym samym nas katolików. Niektóre z tych problemów zasygnalizował Prymas Polski abp Wojciech Polak w rozmowie opublikowanej w sierpniowym numerze miesięcznika „W drodze”, zwracając uwagę, że „w Kościele mamy ludzi o różnych poglądach i musimy o tym pamiętać." Wśród innych wyzwań staje problem nie tyle nawet katechezy dzieci, co bardziej „solidnej katechezy dla rodziców”, którą Prymas określił jako: „nasz wielki deficyt”. Można zatem zastanowić się czy zmianie nie powinny ulec formy działalności Klubów Inteligencji Katolickiej, które powinny dawać świadectwa innym, czym może być społeczne nauczanie Kościoła. Potężnym wyzwaniem jest także wyraźny spadek powołań kapłańskich i zakonnych i tłumaczenie tego tylko niżem demograficznym nie do końca wyjaśnia problem. Wzrasta liczba wniosków o stwierdzenie nieważności małżeństwa z 1250 w 1989 roku do ponad 3700 w 2016 roku, wskazuje z jednej strony na mniejszą trwałość małżeństwa, ale jednocześnie dowodzi, czego nie wolno zapominać, że drugi związek te osoby chcą zawrzeć w Kościele. Kościół rzymskokatolicki, mój Kościół - co wyraźnie podkreślam - czeka trud starań o ludzi młodych, gdyż oni są przyszłością nas wszystkich. Ale młodzież, której nierzadko zarzucamy konsumpcjonizm zawsze bardziej krytyczna od starszych, jest przy tym uważnym obserwatorem życia i bez żadnych kompleksów będzie reagować na podwójne standardy w życiu społecznym. Stąd, w moim 
przekonaniu, w najbliższych latach, nieodwracalnego procesu postępującej atomizacji społeczeństwa, OGROMNIE wzrośnie waga osobistego przykładu i postępowania każdego bez wyjątku przynależącego do wspólnoty Kościoła rzymskokatolickiego.

W konkluzji pragnę zwrócić się do Alumnów rozpoczynających i kontynuujących formowanie kapłańskie słowami Prymasa Wojciecha Polaka cytuję: „... tylko wiara i chrzest. To jest fundament, na którym możemy budować coś więcej." 